\title{
The Effect of Teachingbooks and Prior Knowledge on Learning Outcome of Geography
}

\author{
$1^{\text {st }}$ Sukma Perdana Prasetya \\ Department of Geography Education \\ Faculty of Social Sciences and Law \\ Universitas Negeri Surabaya \\ Surabaya, Indonesia \\ sukmaperdana@unesa.ac.id
}

\author{
$2^{\text {nd }}$ Daryono \\ Department of Geography Education \\ Faculty of Social Sciences and Law \\ Universitas Negeri Surabaya \\ Surabaya, Indonesia \\ daryono@unesa.ac.id
}

\author{
$3^{\text {rd }}$ Murtedjo \\ Department of Geography Education \\ Faculty of Social Sciences and Law \\ Universitas Negeri Surabaya \\ Surabaya, Indonesia \\ murtedjo@unesa.ac.id
}

\begin{abstract}
The purpose of this study are: (1) explaining the difference of learning outcomes between students using teaching book in hardcopy form, teaching book in softcopy form and students without using instructional technology of geography (ITG), (2) explain differences in learning outcomes in terms of prior knowledge variations, (3) explain the interaction between the use of teaching books and prior knowledge on learning outcomes. This research type is a quasiexperiment. Research subjects are students of Geography Education, Faculty of Social Science and Law, Surabaya State of University who program the course of the instructional technology of geography (ITG). The research step is divided into three main stages: (1) experimental preparation, (2) implementation of the experiment, dan (3) post-experiment. Data analysis includes two stages, namely: (1) Test data prerequisite in the form of data normality test with Kolmogorov-Smirnov and Shapiro-Wilk, and test homogeneity of data with Levene test, (2) Hypothesis test using one path anocova analysis. The results of data analysis show: (1) There is a significant difference of ITG learning outcomes between student groups studying with ITG hardcopy teachingbooks, ITG softcopy teachingbooks and without ITG teachingbooks, (2) There is a significant difference in ITG learning outcomes between students with different prior knowledge, (3) There is an interaction between ITG book and prior Knowledge of students on ITG learning outcomes.
\end{abstract}

Keywords — Teachingbook, Prior Konowledge

\section{INTRODUCTION}

In studying the geography of things that must be considered and understood not just memorize facts or concepts, but also connect between concepts to produce an analysis of the process of the occurrence of a phenomenon on the surface of the earth. Learning geography can be used as the basis for the development of mindset based on spatial approach, environment and regional complex in understanding a phenomenon that occurs in a space. It is expected to trigger learners to cultivate the intelligence of thinking about space.

The need to build space intelligence in today's geographical learning ideally and reality is related to the development of theory and practice in the classroom to achieve learning objectives. To achieve the intelligence is done by digging, growing, and provide optimal motivation through the process of learning the right as well.
In the learning process, there are three main components, namely: (1) learning conditions, (2) learning strategies, and (3) learning outcomes [1]. Associated with learning strategies in the form of delivery of messages, materials, and information, required a variety of adequate learning resources, which can be a teaching book.

The optimal learning process in addition to preparing methods, strategies, and media, teachers also need to use teaching books. Teaching book is one component of a learning system that plays an important role in helping students to achieve competence. Teaching book is a book that is used as a learning tool in lectures to support learning programs, especially subjects Instructional Technology of Geography (ITG).

The benefits of teaching books are as follows: 1) Can accelerate discussion of study materials, 2) Students can learn materials of study that will train early, 3) In textbook can also be inserted exercises that must be done student-oriented contextual problems, 4) Problem can be made based on textbook value more just according to the student's ability, 5) the student has one of the references to complete the task

The change of education domain occurs in learning media use in which electronic book (called e-book) starts to develop today replacing previous book used manually or hardcopy form [2]. The teachingtbook developed in this study consists of two versions, namely ITG teachingbooks in hardcopy or print form and ITG teachingtbooks in softcopy or electronic form (Pdf form). The softcopy teachingbooks is a developed book containing writing, drawing, which can be read through a computer device or other digital device.

The existence of these two forms of teachingbook has been much developed in the market, even since 2006, the Ministry of National Education has disseminated Electronic School Books (ESB) which can be accessed free of charge by the community to improve the quality of education. On the other hand printed books still exist in the market, but there has been no research which is more effective than the use of the second book version.

In addition to the delivery strategy factor by using teachingbooks, there are many other factors that also affect the achievement of learning outcomes. One such factor is the 
learning condition. Regarding the condition of learning, Reigeluth and Alison [3] put forward as follows:

"Instruction conditions; all other factors that influence the selection or effect of methods. We have identified four major kinds of instructional conditions; (1) content, (2) learner, (3) learning environment, and (4) instructional development contains".

Reigeluth and Merril grouping learning condition variables into three groups, namely; (1) objectives and characteristics of the subject, (2) obstacles in the lesson, and (3) the character of the learners [4]. Thus in the implementation of the strategy of delivering the material with teaching books need to be considered the characteristics of learners. Among the few characteristics of learners selected and suspected to affect learning outcomes is the initial knowledge of learners.

Prior knowledge becomes the provision of skills possessed by learners. By understanding the concept of a good beginning and depth, then learners will not have difficulty meaningful to learn and master and understand the subject matter next. The theory of learning that became the foundation of prior knowledge theory is a meaningful learning theory by David Ausubel. Meaningful learning is a process of linking new information to relevant concepts contained in a person's cognitive structure. In order for meaningful learning to occur, new concepts or new information must be linked to existing concepts in the cognitive structure of learners. Based on the theory of Ausubel, in helping learners instill new knowledge of a material, it is necessary the initial concepts that have been owned by learners related to the concept to be studied.

The objectives of this research are: (1) to explain the difference of learning outcomes between students using ITG teaching book in hardcopy form, teaching book in softcopy form and without teaching book, (2) to explain the difference of student learning outcomes that have different initial knowledge, (3) explains the interaction between the use of teaching books and initial knowledge on learning outcomes.

\section{METHOD}

\section{A. Research Design}

The variables in this research are the independent variable, covariate variable, and dependent variable. The independent variable is the implementation of the escort by applying ITG teaching book in hardcopy, softcopy and without teaching book. The covariate variable is the student's prior knowledge. The dependent variable is the cognitive domain learning outcomes measured at the level of understanding relationship and applied skills that are classified in the Reigeluth learning taxonomy [5].

This research type is a quasi-experiment. The design of this study can be seen in the following table:

TABLE 1. RESEARCH DESIGN

\begin{tabular}{|c|c|c|c|}
\hline Kelompok & Pretest & Perlakuan & Posttest \\
\hline 1 & $\mathrm{O}_{1}$ & $\mathrm{X}_{1}$ (hardcopy teaching book) & $\mathrm{O}_{2}$ \\
\hline 2 & $\mathrm{O}_{1}$ & $\mathrm{X}_{2}$ (softcopy teaching book) & $\mathrm{O}_{2}$ \\
\hline 3 & $\mathrm{O}_{1}$ & $\mathrm{X}$ (without teaching books) & $\mathrm{O}_{2}$ \\
\hline
\end{tabular}

B. Research Subject
The subjects of the study were students of Geography Education, Faculty of Social Science and Law, the State University of Surabaya who programmed Geography Learning Technology. Research subjects consist of three groups, namely: Class A of 30 students (hardcopy teaching book), class B number of 30 students (softcopy teaching book) and class $\mathrm{C}$ (control class / without teaching book) a number of 31 students.

\section{Research Procedures}

\section{Experiment Preparing Phase}

The research activities begin with a preliminary study covering the preparation of research instruments and discussions with lecturers in the subjects of Instructional Technology of Geography (ITG). The initial stage prepared in this research is to prepare the necessary instruments as data gathering tools and implementation tools from the experiments. Aspects studied in the early stages of the study are: (1) the state of lecturers, students, learning resources and supporting facilities; (2) the application of ongoing learning; (3) lecturer's initial view on learning using ITG teaching book. The instruments used in this study are: (1) a set of tests to test ITG G material learning outcomes, (2) semester learning plan, (3) lecture unit, (4) teaching books (5) observation sheets.

After the learning tools are arranged then proceed to the practical activities. Lecturers are given instructional tools and asked to observe and study the learning devices. After the lecturer understands the steps of applying the lesson, the lecturers practice the lecture by using ITG teaching book.

\section{2). Experiment Implementation Phase}

In the implementation of the experiment applied the following steps: (1) implementing pretest by using test result instrument in essay form to test student's early ability about ITG material to be studied, (2) implementing learning treatment (experiment), (3) implement postest. Students are given lessons by using the prepared lesson plans. The ITG teaching materials design for students in this study is a series of learning components used as experiments or treatment. The ITG learning process was treated for eight meetings.

The ITG lectures by applying teaching books are given to all students with different prior knowledge variations. Learning outcomes are obtained from evaluation activities using the same instrument as when implemented pretest. This is to determine the extent to which teaching books can improve learning outcomes ITG material, especially in understanding the relationship and application of skills before and after implemented learning.

\section{3). Post-Experiment Phase}

After the experimental activity in the form of teaching treatment during the eight meetings has been conducted, then the three groups were given the final test or post tes. This final test aims to determine the effect of treatment on the three groups on the results of learning ITG on cognitive aspects and interaction influence between independent variables and covariate variables on learning outcomes. 


\section{Data Analysis}

\section{1). Test Assumptions}

Before the hypothesis is tested first, the data distribution normality test with Kolmogorov-Smirnov and Shapiro-Wilk test is done through the program and test of data homogeneity with Levene test. Test the normality of the dependent variable data distribution seen in various ways, in order to obtain strong conclusions. The size of normality and homogeneity is based on a $95 \%$ confidence level.

\section{2). Hypothesis testing}

To test the hypothesis whether there is the influence of teaching book application to learning outcomes ITG?, is there any influence of prior knowledge on ITG learning outcomes, and whether there are a teaching book interaction and preliminary knowledge on the learning outcomes of ITG, then the data is analyzed through anakova test with $95 \%$ confidence level.

\section{RESULTS AND DISCUSSION}

\section{A. Result}

\section{1). Data Description of Prior Knowledge}

The data of the pre test result given to the students in the three classes amounted to 91 . Each group has varying initial knowledge (pretest) that is described as follows: (1) students who have pretes by applying hardcopy books have the highest score of 77 and the lowest score 32, an average score of 54.88; (2) Students who have pretest by applying softcopy book have the highest score 76, lowest score 49, score average 63; (3) Students who have a pretest without using a book have the highest score of 74 , the lowest score is 42 , the average score is 60 .

\section{2) Description data of Post Test learning outcomes}

Each group has a varied learning outcome (post-test) which is described as follows: (1) Students who have posttest by applying hardcopy books have the highest score of 100 and the lowest score of 64, an average score of 89; (2) Students who have a pretest by applying softcopy book has the highest score 94, the lowest score 66, the average score 80 ; (3) Students who have a pretest without using a book have the highest score 90 , the lowest score 62 , the average score of 78 .

\section{3). Testing Data Normality}

\section{a). Test Data Normality Viewed from Prior Knowledge}

The results of the Lilliefors Significance Correction test of Kolmogorov-Smirnov and Shapiro-Wilk can be summarized as follows: (1) through Kolmogorov-Smirnov test obtained preliminary knowledge on all groups, the level of significance or probability above $0.05(0.200,0.200$ and 0.138 greater than 0.05 ), it can be concluded that the distribution of the three initial knowledge data is normal, (2) through the Shapiro-Wilk test obtained preliminary knowledge on all groups, the level of significance or probability above $0.05(0.243,0.906$ and 0.118 greater than $0.05)$, it can be concluded that the distribution of the three initial knowledge data is normal. b). Test Data Normality Viewed from Learning Outcomes

The results of the Lilliefors Significance Correction test of Kolmogorov-Smirnov and Shapiro-Wilk can be summarized as follows: (1) through the Kolmogorov Smirnov test obtained for either posttest learning outcomes, significance or probability levels above $0.05(0.118,0.155$ and 0.200 greater than 0.05 ), it can be concluded that the distribution of the three data learning outcomes based on posttest is normal, (2) through Shapiro-Wilk is obtained either for learning outcomes of the posttest, the level of significance or probability above $0.05(0.115,0.475$ and 0.351 greater than 0.05 ), it can be concluded that the third distribution of data learning learning outcomes is normal.

\section{4). Testing Data Homogeneity}

From the calculation of learning result, data obtained Levene Levene test results seen the level of significance or the average probability is above $0.05(0.380$ greater than $0.05)$. Similarly, if the measurement basis is the median data the significance number is 0.555 which remains above 0.05 . Then it can be concluded that $\mathrm{H} 0$ is accepted, so it can be interpreted that the variance of the homogeneous sample. Taking into account the test results of these two assumptions, namely the normality test and homogeneity test, it can be concluded that for testing the analysis of variance with covariates (anakova) can be done.

\section{5). Hypothesis Testing of Research}

This test is performed to prove the truth of the proposed hypothesis. The proposed hypothesis are: (1) there is significant difference of ITG learning result between students who carry out learning with ITG hardcopy teachingbook, ITG softcopy teaching book, and without book (2) there is significant difference of ITG learning result among students having different initial knowledge, (3) there is a significant interaction between the use of ITG teaching books with initial knowledge of the learning outcomes of ITG.

Hypothesis testing is done by analyzing the test data of ITG learning result. After calculation of covariance analysis technique (One-way Anakova). On average, students using hardcopy books (89) were higher than students using softcopy (80) and without using books (78).

TABLE 2. TESTS OF BETWEEN-SUBJECTS EFFECTS

\begin{tabular}{|l|l|c|c|c|c|}
\hline \multicolumn{1}{|c|}{ Source } & $\begin{array}{c}\text { Type III } \\
\text { Sum of } \\
\text { Squares }\end{array}$ & df & $\begin{array}{c}\text { Mean } \\
\text { Square }\end{array}$ & F & Sig. \\
\hline Corrected Model & $3360.395 \mathrm{a}$ & 3 & 1120.132 & 18.846 & .000 \\
\hline $\begin{array}{l}\text { Intercept } \\
\text { ITG*prior know. }\end{array}$ & 6300.448 & 1 & 6300.448 & 106.005 & .000 \\
\hline ITG & 3125.445 & 2 & 1562.722 & 26.293 & .000 \\
\hline Prior know. & 1144.206 & 1 & 1144.206 & 19.251 & .000 \\
\hline Error & 5170.901 & 87 & 59.436 & & .000 \\
\hline Total & 626004.000 & 91 & & & \\
\hline Corrected Total & 8531.297 & 90 & & & \\
\hline
\end{tabular}

Based on the table Tests of Between-Subjects Effects, value of significance or probability Treat with ITG book and preliminary knowledge is 0,000 which means smaller than the significance level of 0.05 , it can be concluded there is a significant difference or significant influence of early knowledge and use of ITG book on study result. In the position of intercept ITG * prior known toward learning 
outcomes has a significance level (0.00), smaller than the 0.05 significance level, it can be concluded there is a significant interaction between prior knowledge and using ITG books on learning outcomes.

\section{B. Discussion}

\section{1). The Influence of Teachingbooks on Learning Outcomes}

The result of hypothesis testing shows that there are significant differences between student groups who learn with ITG hardcopy teaching book, softcopy and without using teaching book. Based on the calculation of the average score, the overall application of ITG hardcopy books has a better effect than the application of ITG softcopy books and without using books on the results of learning ITG. It is seen from the average value obtained from the application of ITG hardcopy book that is 89 higher when compared with the average score obtained by the group of ITG softcopy is 80 and the group without using the book is 78. From the results of this study revealed that the results of learning ITG students who are taught by hardcopy books is higher than the results of learning ITG students who were taught by books softcopy, then this can be taken into consideration for lecturers Geography to use teaching book in the form of hardcopy, especially on subjects Instructional Technology of Geography.

Based on research reports and journal articles that raised the teaching book as research variables have been implemented several times. Research results of Milligan et al,[6]; Marinkovic et al, [7]; Mohammadi and Abdi [8], which uses teachingbooks as research variables, shows that an interesting teachingbook strategy is very effective in improving learning outcomes. The findings research of Joo et al,[9] revealed that the existence of teachingbooks gives a better influence in improving students' critical thinking skills than without using teachingbooks. Based on the findings of the study, it seems that the use of teachingbooks is important to apply in ITG materials. There are several factors that cause the acquisition of learning outcomes in teachingbooks ITG has advantages.

First, based on the results obtained data processing revealed that ITG hardcopy teachingbooks get superior learning outcomes than the teachingbook ITG softcopy and without teachingbooks ITG. The advantages of ITGteachingbooks because ITG teachingbooks are made in accordance with ITG material characters. ITG hardcopy books give students the opportunity to analyze existing problems through literacy learning activities. According to Prasetya [10], the application of geographical teachingbooks that are interesting and appropriate to enhance understanding and skills that are geospatial (space on earth). ITG is one of the sources to recognize various designs, models, development, and learning media. Learning-related issues need to be solved solely by students through strong literacy studies and analyzes.

Second, the ITG book can challenge students 'ability and provide an opportunity to determine new knowledge for the students because new knowledge is obtained based on the students' schemata so that learning is more meaningful. The importance of meaningful learning is affirmed by Joyce, Weil and Calhoun [11], which revealed that the essence of teaching is to help students gain meaning from the activities of students who process information, ideas, skills, values, ways of thinking, the means to express themselves, and how to learn. The meaning of learning that is owned by students plays an important role. According to the constructivist theory of learning is an effort to give meaning to students to their experience through assimilation and accommodation that leads to the direction of forming its cognitive structure [12].

Third, the ITG book can help students how to transfer their knowledge to understand real-life issues. The ITG book can improve students' understanding of what they learn so that they can apply it in conditions in their daily lives. Students are not only able to remember the subject matter but to master and fully understand, the subject matter of the substance to be studied. Thus the students become more powerful understanding of the concepts taught by lecturers in the learning process. In relation to ITG material learning, students are expected to master a variety of conceptual understanding to solve problems in producing products. Students are given the opportunity to solve problems that are contextual and they learn and work together in groups, openly pour ideas through discussion. Student activeness is expected among others the liveliness of sharing knowledge among students, asks, argues, and likens the perception of problem-solving provided. Student involvement actively in discussions can build and develop cognitive thinking skills. Cognitive thinking ability can help students to get learning outcomes on cognitive aspects, especially cognitive aspects at a higher level than memorization. Dryden and Vos [13] argued that the application of teachingbooks can also optimize the learning experience, such as observing experience, recording data, and conducting a literature review, and communicating knowledge. Learning that involves the entire senses will be more meaningful than one sense alone. This is reinforced by the opinion of Silberman [14] that in order to achieve optimal learning outcomes learning must be multisensory and full of variations.

Fourth, According to Sanjaya [15] Some of the advantages of using teaching books in learning are: (1) teaching book is a good technique to better understand the contents of the lesson, (2) teaching books can challenge the ability of students and give satisfaction to find new knowledge for students, (3) teaching books can enhance student learning activities, (4) teaching books can help students how to transfer their knowledge in understanding real-life problems, (5) teaching books can help students to develop new knowledge and be responsible in their learning, (6) teaching books can develop students' ability to think critically and develop their ability to adjust with new knowledge, (7) teaching books can provide opportunities for students to apply their knowledge in the real world, (8) teaching books can develop student interest to continuously learn, even though learning on formal education has ended.

\section{2). The Effect of Prior Knowledge on Learning Outcomes}

In hypothesis testing concluded that there is a significant difference between the initial knowledge variation on the learning outcomes of ITG. The higher the initial knowledge of students, the higher the learning achievement. A set of factors that contribute to learning to learners is the ability that has been owned before following the new learning activities [16]. When associated with the initial ability of the 
learner, the initial ability is the basic capital for a person to learn the next material to be studied. If a person's prior knowledge is high then learners will be easy to learn new material to be learned, and he will not experience significant learning difficulties so that learning achievement will be more leverage. Observing efforts to improve learning outcomes is not uncommon to find a student who lacks the passion in solving problems to be solved, especially the source of learning what is most appropriate to him and can be used to solve the problem. This condition results in a lack of achievement of learning outcomes. Lack of success in learning one of them caused by the identification of prior knowledge in learning, especially the use of teaching books in lectures ITG.

Prior knowledge to describe readiness of learners in receiving lessons to be delivered. The initial ability of learners is important to know the teacher before starting the learning because it can be known whether learners have had initial knowledge which is a prerequisite to follow the learning, the extent to which learners know what material to be presented. Provision of appropriate initial knowledge of the learners well and deeply, then learners will not have difficulty meaningful to learn and master and understand the subject matter further. Prior knowledge referred to in this study is the initial ability of students from the results obtained by the value of learners through the test on ITG material before the students obtain material that will be the material in the study. From the value of the test on the material obtained by learners used as a benchmark of the initial ability of learners to know the level of mastery of the material and understanding the concept of learners before receiving the material ITG.

3). The Influence of Interaction between Teachingbooks and Prior Knowledge on Learning Outcomes

In testing, hypothesis obtained the conclusion that there is an interaction between ITG teaching book application and prior knowledge to result in learning ITG. Based on the results of descriptive research and hypothesis testing using anacova analysis techniques revealed that the achievement of student learning outcomes is not only a result of the application of teachingbooks, but also influenced by the characteristics or conditions of students in the form of prior knowledge.

Teachingbooks are designed for independent learning systems with a systematic and intact learning program and are presented communicatively. The existence of learning resources by using teaching book will make it easier for students to learn effectively [17]. When associated with the prior knowledge, the learning process sooner or later learners, one of which is influenced by the ability of the learners themselves. If the learners have a high ability then the learning process will be easier and faster, but also vice versa if the ability of learners low then the learning process will tend to slow and long, so less learning achievement maximum [18]. Teaching materials are an external factor of students who are able to strengthen the internal motivation to learn. One of the learning activities that can influence the learning activities is the use of teaching materials that can make learners more motivated to learn but the material is still relevant to the applicable curriculum. The reader's prior knowledge of a book can improve the effectiveness of knowledge [19],[20]. Student learning outcomes can be obtained optimally through the active interaction between delivery strategies (such as the use of teaching books) by linking the knowledge being studied with the prior knowledge they have.

\section{CONCLUSION}

Based on data processing and discussion of research results, then in this study can be concluded that (1)ITG learning outcomes between students who studied with ITG hardcopy teaching books, ITG softcopy teaching books and without using ITG teaching books differ significantly. Overall learning outcomes of ITG students taught by ITG hardcopy teaching books are higher than the results of learning taught with ITC softcopy teaching books or those taught without ITG teaching books. It can be concluded that ITG hardcopy books have a better influence on ITG learning results than ITG softcopy books or without ITG teaching books; (2)There are significant differences in ITG learning outcomes between students who have Prior knowledge variations. Students with higher prior knowledge will have better learning outcomes than those with low prior knowledge.

Higher prior knowledge scores better than low prior knowledge, in all three groups, applied (ITG hardcopy teaching books, ITG softcopy teaching books, and without using ITG teaching books); (3) There is an interaction between teaching books and prior knowledge variations on ITG learning outcomes. The best ITG learning outcomes are in students who have a high initial skill tendency and are taught by ITG hardcopy teaching books. Thus it can be said that the learning outcomes of ITG are strongly influenced by the use of teaching books and student prior knowledge trends.

\section{ACKNOWLEDGMENT}

The authors would like to thank the University state of Surabaya for their support and assistance for the research program held in 2017. Dean of Faculty of Social Science and Law, Prof. Dr. Sarmini, M.Hum, for her contribution and attention in facilitating faculty policy research activities.

\section{REFERENCES}

[1] C. M. Reigeluth, Instructional-Design Theories, and Models: An Overview of Their Current Status. Vol. I. New Jersey: Lawrence Erlbaum Associates, Publishers, 1983.

[2] D. Astuti, Siswandari, and D. Santosa, "E-Book for Problem Based Learning to Improve Learning Outcome of the Students Dwi Puji Astuti 1, Siswandari 1, Djoko Santoso Th 1 1," Adv. Soc. Sci. Educ. Humanit. Res., vol. 158, no. Ictte, pp. 220-227, 2017.

[3] C. M. Reigeluth and A. Alison, Instuctional-Design Theories and Models. Vol. III. New York: Publishing Routledge. Taylor \& Francis Group, 2009

[4] C. M. Reigeluth and M. D. Merill, "Classes Instruction Variables," Eductional Technol., vol. 3, pp. 5-24, 1979.

[5] C. M. Reigeluth, Instructional-Design Theories and Models; A New Paradigm of Instructional Theory. Vol. II. New Jersey: Lawrence Erlbaum Associates Publishers, 1999.

[6] L. O. Milligan, L. Tikly, T. Williams, J.-M. Vianney, and A. Uworwabayeho, "Textbook availability and use in Rwandan basic education: A mixed-methods study," Int. J. Educ. Dev., vol. 54, pp. 1-7, May 2017. 
[7] S. Marinković and M. Erić, "The Problem of Value in a Textbook," Procedia - Soc. Behav. Sci., vol. 128, pp. 72-76, Apr. 2014.

[8] M. Mohammadi and H. Abdi, "Textbook Evaluation: A Case Study," Procedia - Soc. Behav. Sci., vol. 98, pp. 1148-1155, May 2014.

[9] Y. J. Joo, S. Park, and E. K. Shin, "Students' expectation, satisfaction, and continuance intention to use digital textbooks," Comput. Human Behav., vol. 69, pp. 83-90, Apr. 2017.

[10] S. P. Prasetya, Learning Media of Geography. Yogyakarta: Ombak, 2014.

[11] B. Joyce, M. Weil, and E. Calhoun, Models of Teaching, 8th ed. Boston: Pearson Education, 2009.

[12] I. N. S. Degeng, Learning Strategies, Organizing Content with Elaboration Model. Malang: In Cooperation with the Publishing Bureau of Professional Educational Technology Association, 1997.

[13] G. Dryden and J. Vos, The Learning Revolution. Bandung: Kaifa, 2003.

[14] I. M. Silberman, Aktive Learning. Boston: Allyn \& Bacon. Inc, 2006.

[15] W. Sanjaya, Learning Strategies: Oriented Standard Education Process. Jakarta: Kencana Prenada Media Group, 2008.

[16] D. A. Jacobsen, P. Eggen, and D. Kauchak, Methods for Teaching. New Jersey: Pearson Education. Inc, Publishings Allyn\& Bacon, 2009.

[17] S. P. Prasetya, "The Effect of Textbooks on Learning Outcome Viewed from Different Learning Motivation," Adv. Soc. Sci. Educ. Humanit. Res., vol. 173, no. 1, pp. 316-318, 2018.

[18] A. M. Subramanian, W. Bo, and C. Kah-Hin, "The role of knowledge base homogeneity in learning from strategic alliances," Res. Policy, vol. 47, no. 1, pp. 158-168, 2018.

[19] Y. Zhang, "The Application of Schema Theory to English Reading Teaching in Junior High School," Adv. Soc. Sci. Educ. Humanit. Res., vol. 13, no. 1, pp. 14-21, 2016.

[20] Z. Yunxiao et al., "Studying and Implementing about the Grading Teaching," Adv. Soc. Sci. Educ. Humanit. Res., no. Cetcu 2015, pp. 20-22, 2016. 